\title{
河川と地下水
}

榧 根勇 ${ }^{*}$

\section{River and Groundwater}

Isamu KAYANE

\begin{abstract}
Both river and groundwater are mode of occurrence of water in the hydrologic cycle. Relation between river water and groundwater are discussed on the basis of groundwater flow system, whose water table configuration is controlled by the topography and the distribution of specific flux within the system by the geology. Examples of the relation are shown for sand dunes, mountains composed of permeable rocks, volcanoes, hills, uplands, alluvial fans and lowlands.
\end{abstract}

\section{I. はじめに}

近年に括ける地下水研究への最大の科学的貢献は, ТÓTH $(1962,1963)$ による地下水流動系という概念 の提示であろう。地下水資源開発や排水工を志向したそれまでの地下水水理学は，地下水流動の場である 帯水層の透水性および貯留性の評価をその中心課題としていた。带水層試験によって透水係数や貯留係数 などの帯水層パラメータが定まれば，帯水層中の地下水の流れは，ダルシー式と連続式から導かれた運動 方程式の解として得られるとするのが, 地下水水理学の立場であった。その際に必要となるのは, 帯水層 試験技術と数理解析技術である。

このように帯水層単元で地下水を問題にすると, 地下水の涵養や流出は, 帯水層中の地下水流動にみあ うものとして, 結果としてしか決まらない。しかし水循環の一環として地下水を考える水文学の立場に立 つと, 先づ問題にすべきは涵養量や流出量である。涵養, 流出条件に規制されて, 地下水の流動状態は決 まるのである。いかに良質の帯水層が存在しても，涵養がなければ定常的な流出は起こりえない。

地下水流動系といら概念の基本は, 地下水を, 涵養一流動一流出といら水循環の過程にある連続系と認 識することにある。地下水は “帯水層中を”ではなく, 帯水層一加圧層群中を三次元的に流動する。自然 界には厳密な意味での不透水層は存在しない。小さなサンプルによる室内試験では透水性 00 岩 盤 中で も，水は割れ目を通って流れる。粘土層とて均質ではない。

地下水流動系の空間構造は, 地形と地質の両方の規制を強く受ける。地形は流動系の上部境界条件とな る地下水面の抢抢よその形状をきめ，地質は系の内部に打ける水のフラックス分布に影響を与える。

地下水流動系は理論のみにより演繹された概念であるが, その実在は, ピエジメータ群による水理水頭 分布の観測や，同位体・水質・水温などをトレーサーとする野外の帰納的研究によって，すでに否定でき ないものとなった。

地下水の涵養源は, 降水, 河川や湖沼などの地表水, および灌溉や注入などで人為的に供給された水で ある。一方, 涵養された地下水は重力の作用で, 河川, 湖沼, 海洋などへ流出する。砂漠などの特殊な条件 下では，地下水が地表水の状態を経ずに，蒸発で直接大気中へ失われることもある。

一般に河川は, 自然界では地下水流動系の流出境界, すなわち排水路として機能している。大縮尺の地

\footnotetext{
* 筑波大学地球科学系 Institute of Geoscience, University of Tsukuba
} 
図上で, 河川の総延長と湖岸線および海岸線の総延長とを計測し, それらを相互に比較してみれば, 排水 路としての河川の機能の重要性が容易に理解できょう。後述するょうに，河川は地下水の涵養源になるこ ともあるが，湿潤地域ではそれは例外的事例に属する。

な抢，TÓTH の論文では，自然界に扔いて地下水面がどのような形状を示すかについては触れていな い。境界条件である地下水面がこのような形であるならば，このような流動系が出現すると述べているだ けである。現実の地下水面は地形に強く規制され，涵養と流出の釣り合いを保つようなある形をとる。し たがって地下水のありかたや, 河川と地下水との関係を考える際には, 地形別に地下水をみる必要が生ず る。

\section{II. 河川と地下水との関係}

日本を地形で区分すると，その面積百分率は，山地が $56 \%$, 火山が $9 \%$, 丘陵が $11 \%$, 台地が $11 \%$, 低地 が13\%になる（中野 1963）。火山も山地だが, 基盤岩からなる山地と火山とでは, 地下水循環の様式がま ったく異なる。次節以下でこれらの地形別に，河川と地下水との関係を考察してみる。

近年の水文学における最も重要な発見の 1 つは, 植生に覆われた中緯度湿潤地域の山地では, いわゆる ホートン地表流は発生しないといら事実である。これは地形の進化にも重要な示唆を与える。地表流が発 生しなければ，地表流による侵食は地形進化の基本的営力にはなりえず，河谷が形成されるためには，そ れに先行矛備的条件が必要になる。たとえば地下水露頭侵食モデル（GOEM）は，大陸水床後退後の 水流発生の主原因を地下水流動系の進化と関連づけている(DE VRIES 1974)。

したがって, わが国の山地，火山，丘陵では，基本的な水循環の方向は，降水一地下水（または地中水） 一河川水となる。すなわち河川水の大部分は地下水（または地中水）で養われている。

この基本的な水の流れの方向は，台地と低地でもわずかな例外を除けば変わらない。しかし，台地と低 地は人間活動が最も活発に行われている舞台である。灌溉，排水，揚水などの人為的影響によって，河川 水と地下水は相互に影響し合っている場合も少なくない。

これまでの地下水調查では, 地質調查と揚水試験がその中心を占めていた。しかしそれだけでは, 地下 水の容れものとしての性質は明らかにできても, 地下水循環の実態はわからない。地下水循環を駆動して いる力は重力であり, 河川への流出量を決めているのは地下水への涵養量である。河川という流出基集面 に対して, 周辺の地下水面がどれだけの高度差をもっているか, そしてその地下水面へどれだけの水が付 加されるか。この 2 点を明らかにするための水文学的調查を, 前述の地下水調查と組み合わせることによ って，地下水循環の実態が明らかになる。

さらに現在の日本では, とくに台地と低地では, 人閒活動により自然界の地下水流動系は著しく乱され ている。したがって地下水循環の現状を明らかにするためには, 前二者の調査に加えて, 人間活動による 地下水の湧源と吸源の分布を明らかにする必要がある。そのことによってはじめて, 涌水の復活, 地下水 人工涵養の効果，地下水污染対策などの地下水にかかかる現実的問題への対処が可能になる。

地下水は，水資源であることのほかに環境資源でもある。都市域においては，清浄な大気や森林と同様 に，地下水は存在することに価值がある。東京をはじめとする多くの都市では，そ机は管理を必要とする 対象であり, 地下水水文学は管理のための科学的基礎を提供することが出来る。

\section{III. 砂丘の地下水}

砂丘は風で運ばれてきた砂粒が堆積して形成された。その表面は波状起伏を示すのが普通であり，砂丘 砂の透水性は高い。たとえば透水係数が $1 \times 10^{-2} \mathrm{~cm} / \mathrm{s}$ であるとすると, $360 \mathrm{~mm} / \mathrm{h}$ となるから, 経験的に知 られているように浸透能を透水係数の半分と見積っても，毎時 $180 \mathrm{~mm}$ の雨を浸透させることができる。 したがって植生の有無にかかわらず，砂丘では表面流出は発生しない。浸透した水は地下水となり，周辺 
SAND DUNE

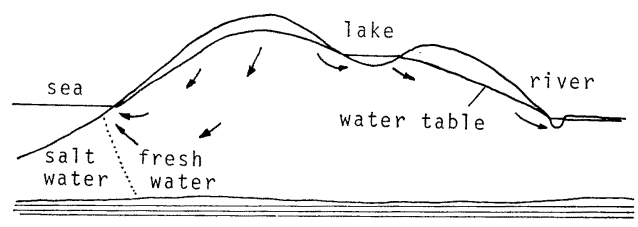

第 1 図 砂丘の地下水と河川
部で流出する。砂丘は一般に均質な砂からなり， このように表面流出はまったく考えなくてもよい から，地下水循環を考える最も単純な事例として 取り上げることができる。

明治時代の 5 万分の 1 の地形図を調 ベてみる 上，砂丘列の閒に砂丘湖の存在する地域が少なく ない。砂丘の地下水面は，実測例によると，地表 面の起伏と類似の形態を示し，地表面の標高の高 いところでは地下水面の標高も高い。

模式的には砂丘の地下水循環は第1図のように表現できよう。砂丘湖は地下水流出と降水で養われてい るが，日本の気候条件では年降水量が年蒸発量をはるかに上回るので，流出河川をむたない砂丘湖では， 池田湖や俱多楽湖などの閉塞カルデラ湖と同様に，湖底からの地下水流出がなければならない。

海に面する砂丘では，波打際付近に地下水の流出が認められる。温泉地帯では加熱された地下水がそこ へ流出し，指宿温泉などではそれを砂風呂として利用している。海岸付近の地下水面標高と塩淡水境界面 深度との間には，静的条件下では Ghyben-Herzberg の関係が成立するが，現実には地下水流出の作用で， 境界面は下方へ押し下げられている。

砂丘の内陸側には, 砂丘から流出する地下水を集める小河川が存在している。砂丘列の構成によっては, 砂丘列間を排水河川が砂丘列と並行に流れる。その典型例は阿賀野川以北の越後平野海岸部でみることが 出来た。

\section{IV. 透水性の山地の地下水}

山地を構成する岩石が比較的均質で透水性の場合には，その透水係数が砂丘砂ほど高くなくとも，砂丘 におけると同じような地下水の流れが生じる。

第 2 図は花崗岩からなる瀬戸内海のある島の地下水面と水理水頭分布の実測結果である。深度別の水理 水頭は，1本の井戸を用いて各深度で井戸内部にパッカーをかけて測定された。透水係数の值は, 表層付 近の風化層で $1 \times 10^{-4} \mathrm{~cm} / \mathrm{s}$ 程度，基盤部では $1 \times 10^{-5} \mathrm{~cm} / \mathrm{s}$ 程度である。地下水の流れは，地表から涵養さ れた水が島の海岸部へ流出する対称的なかたちになっており，図に示す流れの実在は，地下水中のトリチ ウム濃度の空閒分布によっても確認された（百田ほか 1981）。

第 3 図は水文調査から得られたこの島の年水収支である。 $\mathrm{P}$ は降水量, $\mathrm{E}$ は蒸発散量, i は地下水涵養 量, Rs は直接流出量, $\mathrm{Rb}$ 注河川への基底流出量, Go は海への地下水流出量である。砂丘亡異なり，この 島には河川が存在するが, 島からの流出に果たす河川の役割は地下水よりも低い。すなわち, 降水量から蒸 発散量を差引いた残り $470 \mathrm{~mm} / \mathrm{yr}$ のうち，350mm/yr は一たんは地下水になってから， $50 \mathrm{~mm} / \mathrm{yr}$ は河川

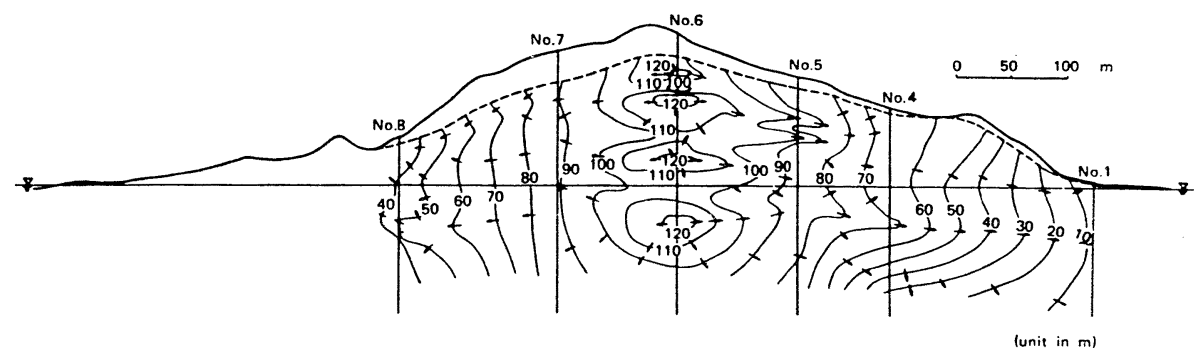

第 2 図 花崗岩からなる島の水理水頭分布（百田ほか 1981） 


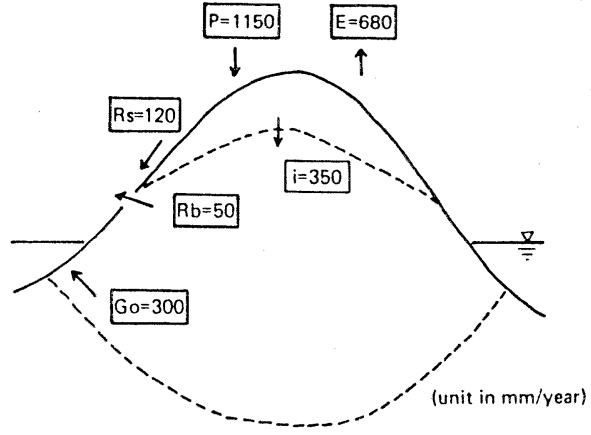

第 3 図第 2 図の島の水収支

（百田ほか 1981）

へ, $300 \mathrm{~mm} / \mathrm{yr}$ は海へ直接, 流出する。これに対

して河川による排水は $120 \mathrm{~mm} / \mathrm{yr}$ にすぎない。

\section{V. 火山の地下水}

火山を構成する岩石も砂丘と同様に透水性は高 い。そのため火山体を刻む河川は，ある 高度以上では，激しい雨のときしか河床 を水が流れていない。第 4 図は阿蘇カル デラ流域の水系図であるが，恒常流の存 在する河川は太線の区間に限られる。そ れ以外の河谷は火山体が吸収できないほ ど強い降雨強度のときだけ流出に関与す る(下津 1986)。

一般に，火山については第 5 図のよう な水文モデルが適用できるとされている（山本 1970）。山頂および山腹涵養帯で涵養された地下水は, 火山体中を流下して山麓で湧水となって流出し，河川を養う。一般的にいって，火山山麓の湧水の，した がってそれによって養われている河川の水質はよく，また水温も標高に比して低めであるため，二ジマス などの養殖に利用されている湧水も多い。しかし地質条件によっては水質の悪い涌水(したがって河川水) もみられる。たとえば，同じ阿蘇カルデラ内の河川であっても，白川はその名のとおり水質がすぐれてい るのに対して，黒川は鉄分などを多く含み水質は悪い。火山地帯から流出する河川の中には，強い酸性を 示す酸性河川もある。

火山体と，砂丘および透水性のよい基盤岩の山体との基本的差異は，火山体を構成する岩石が均質では ない点である。これは地下水の流れに決定的差異を生じさせる。火山体中の地下水は，重なり合う溶岩と 溶岩の間や割れ目などの限られた部位を集中的に流れている。したがって，火山体中の地下水循環を第 1 図や第 2 図のように模式化するのは危険である。

\section{VI. 丘陵の地下水}

わが国の丘陵の多くは第三系〜第四系の比較的未固結な堆積層の地域が隆起し，侵食を受けて形成され た。丘陵は地形形態による分類で，成因や内部構造を問題にしてはいないので，ペディメントの開析され たものを丘陵に含めることもあるが，本稿ではこの種の丘陵や火山性の丘陵は取り上げない。 


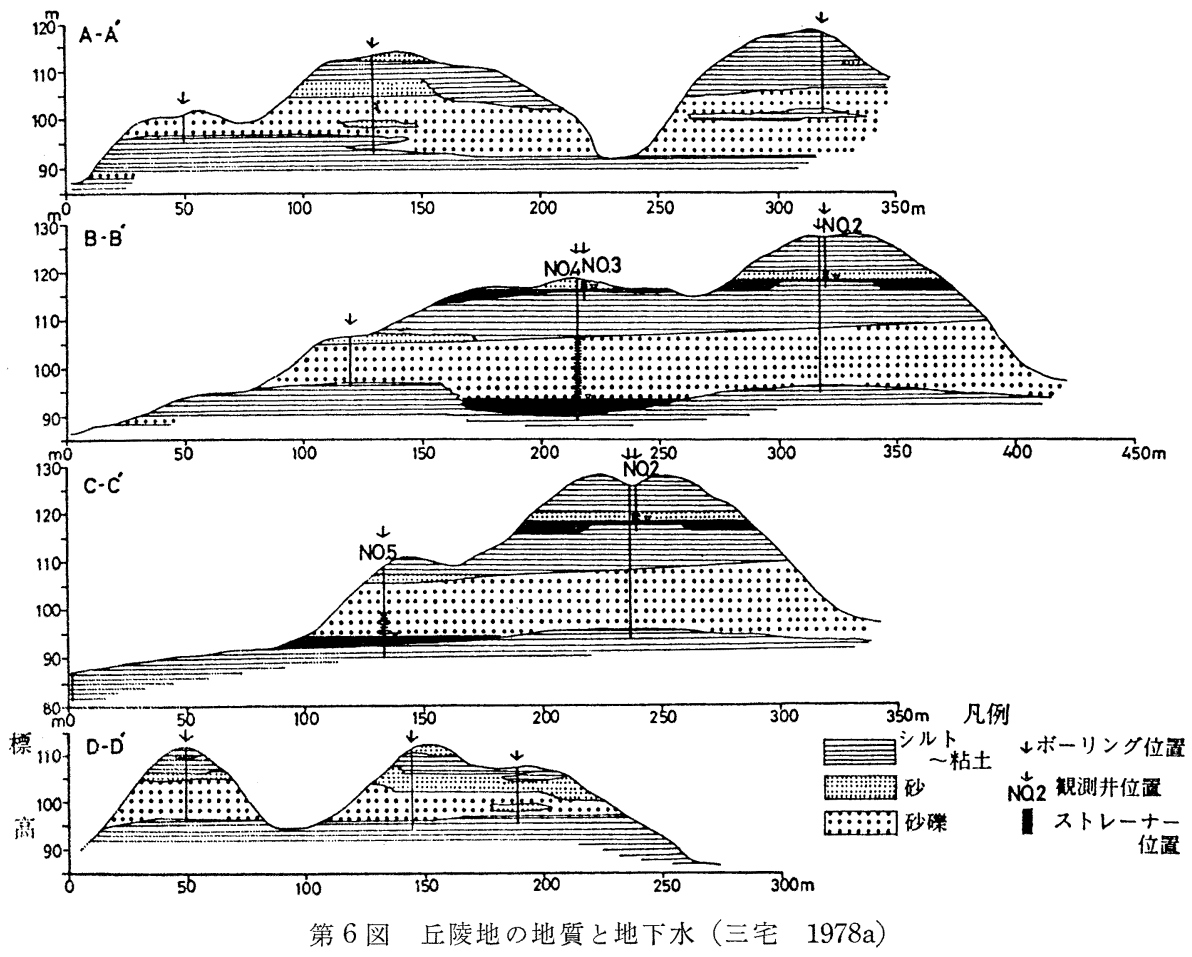

第 6 図は, 明石市街地の北方約 $10 \mathrm{~km}$, 明石川に刻まれた大阪層群の丘陵小流域の地質断面図であるが, わかりやすいように帯水層中に地下水の存在する部分を筆者が黒く塗って示した（三宅 1978a）。地下水 面の存在は観測井で確認された。

成層構造をもつ丘陵の地下水の分布特性は，地下水もまた成層構造を示すことである。第 6 図の B- $\mathrm{B}^{\prime}$ や C-C $\mathrm{C}^{\prime}$ 断面では上下 2 つの地下水面が存在し, 両者の中間には不飽和帯がある。一方, A-A と は明膫な地下水面が認められない。丘陵を刻む谷は侵食深度が深く, 主帯水層である砂層や砂碩層は比較 的透水性が良いので, 地下水が排水されるための条件は整っている。一方, 一般的にいって, 丘陵地域は 山地地域よりも降水量が少ないので, 地下水の涵養条件は山地よりも悪い。そのため, 丘陵内部の地下水 は連続体として取り扱うことが出来ない場合が多い。

このことは, 河川と地下水との関倸を考えるとき重要になる。すなわち, 河川がどの帯水層の地下水を 排水しているかによって, 河川の流出特性に差異が生ずる。三宅（1978b）はこの丘陵地における河川流量 の継続観測結果から, 調查流域の渴水期間に掞ける基底流出は主要帯水層への地下水の涵養量と関係があ り，このような場合には基底流出は指数関係的な莪減特性を必ずしも示さないことを明らかにしている。

丘陵地がその山体中に大きな不飽和空間をもつことは，条件次第では丘陵が大量の降雨を一時的に貯留 する機能を持ちうることを意味する。MARUI（1986）は多摩丘陵源流谷頭部で流量観測を行い，ひと雨降 雨と流出量との関係を第1 表のようにまとめている。降雨番号 6 までに合計 $119.5 \mathrm{~mm}$ の降雨があったが, この流域からの流出は 0 であった。番号15 22の降雨についても流出量は測定可能量以下であった。

この流域は, 流量観測用パーシャルフリュームの標高と分水界との比高が約 $23 \mathrm{~m}$ で, 分水界付近では上 位から厚さ約 $4 \mathrm{~m}$ の関東ローム層, 約 $16 \mathrm{~m}$ の御殿峠碷層, それ以下は透水性の低い蓮光寺互層となって

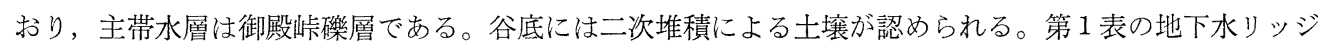


第 1 表 多摩丘陵源流部に扮ける降雨と流出（MARUI 1986）

\begin{tabular}{|c|c|c|c|c|c|c|}
\hline 降雨番号 & & 月・日 & $\begin{array}{l}\text { 総降水量 } \\
(\mathrm{mm})\end{array}$ & $\begin{array}{c}\text { 流出率 } \\
(\%)\end{array}$ & $\begin{array}{l}\text { 地下水 } \\
\text { リッシ }\end{array}$ & $\begin{array}{l}\text { 関東口ーム層 } \\
\text { 中の地下水 }\end{array}$ \\
\hline 1 & \multirow[t]{3}{*}{ May } & $20-21$ & 16.5 & 0 & $x$ & $x$ \\
\hline 2 & & $24-25$ & 16.0 & 0 & $x$ & $x$ \\
\hline 3 & & 29 & 12.5 & 0 & $\times$ & $\times$ \\
\hline 4 & \multirow[t]{6}{*}{ June } & $10-11$ & 6.5 & 0 & $\times$ & $?$ \\
\hline 5 & & $12-14$ & 68.0 & 0 & $x$ & $x$ \\
\hline 6 & & 20 & 104.0 & 21.4 & 0 & 0 \\
\hline 7 & & 24 & 9.5 & 0 & 0 & $\times$ \\
\hline 8 & & 26 & 46.5 & $*$ & 0 & $\times$ \\
\hline 9 & & 28-July 1 & 205.0 & 92.5 & 0 & $\bigcirc$ \\
\hline 10 & \multirow[t]{6}{*}{ July } & 3 & 4.5 & 0 & 0 & $x$ \\
\hline 11 & & 11 & 19.0 & $*$ & 0 & $?$ \\
\hline 12 & & 12 & 40.5 & $*$ & 0 & $?$ \\
\hline 13 & & 13 & 9.0 & 7.2 & $\bigcirc$ & $?$ \\
\hline 14 & & 14 & 53.5 & 55.5 & 0 & $?$ \\
\hline 15 & & 21 & 17.5 & $*$ & 0 & $x$ \\
\hline 16 & \multirow[t]{2}{*}{ Aug. } & $10-11$ & 82.0 & $*$ & $\times$ & $\times$ \\
\hline 17 & & 30 & 57.0 & $*$ & $x$ & $x$ \\
\hline 18 & \multirow[t]{3}{*}{ Sept. } & $14-15$ & 22.5 & * & $x$ & $x$ \\
\hline 19 & & $23-24$ & 41.5 & $*$ & $x$ & $x$ \\
\hline 20 & & 29 & 31.0 & $*$ & $x$ & $x$ \\
\hline 21 & \multirow[t]{2}{*}{ Oct. } & 6 & 44.5 & $*$ & $x$ & $x$ \\
\hline 22 & & 11 & 5.5 & $*$ & $\times$ & $x$ \\
\hline
\end{tabular}

* : 流出量測定限界以下

$\bigcirc$ : 観測された

×：観測されなかった

は，主帯水層中の谷底近くで降雨による涵養によって地下水面がリッジ状に盛り上っている状態を指す。

第 1 表から, この丘陵谷頭部の源流域からは, ある程度の降雨が山体内に蓄えられたあとでなければ, 地下水流出は発生しないことがわかる。なおこの丘陵では, 豪雨時でも表面流出は発生せず（YASUHARA 1984，太田ほか 1985), 源流部の水流は地下水流出のみによって発生することが知られている (TANAKA et al. 1986)。

\section{VII. 台地の地下水}

わが国の洪積台地は，隆起運動の激しい島弧に特有の地形である。筆者らが diluvial upland の地下水に 関する論文 (BAE and KAYANE 1987) をイギリスの雑誌に投稿したとき，“洪水につかる台地”という用 語は㧍かしいとして diluvial upland を別の用語に書き換えるよう修正を求められた。わが国では洪積台 地滈等学校の教科書にものっているので, 日本特有の地形ということで, 今後柔道の ippon や wazaari と同じように，英語でも kosekidaichi と呼んだらいかがなものであろうか。

洪積世（更新世）に形成された台地でも，かつての平野や浅海底が降起して侵食された台地と，火砕流 の堆積で形成された台地とでは性質はまったく異なるので，別々に考察する必要がある。

関東地方平野部に広く分布する洪積台地は，前者の代表例である。その 1 例として，霞ケ浦へ半島状に 


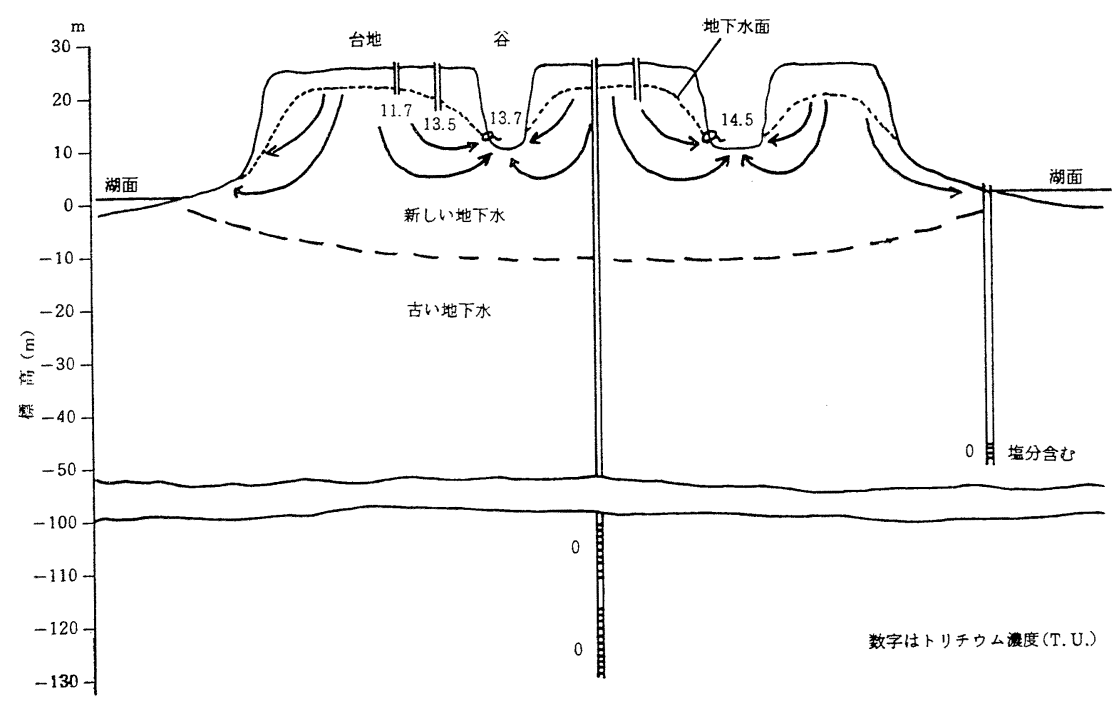

第 7 図 出島台地の地下水循環模式図

突き出ている出島台地を例に地下水と河川との関係を考察してみよう。この台地は西北西から東南東方向 に傾斜し， 2 つの必従谷とそれらの支谷が台地面を開析している。主谷底と台地面との比高は $10 \sim 20 \mathrm{~m}$ で ある。第 7 図は，この台地を主谷と直交する方向に切った断面における地下水循環の模式図であり，実測 した地下水中のトリチウム濃度のいくつかも記入してある。

滞留時間分布関数を正規分布と仮定して，たたみ込み積分により解析すると，第 7 図の古い地下水の年 齢は 40 年以上，新しい地下水は 10 年未満と求まる。すなわち，台地面から涵養された水は，平均約 10 年経 過してから谷へ流出して河川水になる (裴・榧根 1987)。台地の開析谷は地下水の排水路として機能して いる。

ところで，ここで注意を要するのは人間活動の影響である。台地の開析谷が谷頭部においてさえ地下水 の排水機能をもつことは，地中の水理水頭の鉛直分布から知られている（新藤・石川 1985）。しかし人為 的な揚水があると，条件次第では河川水が地下水を涵養することも起こる。第 8 図は同じ台地の地下水三 次元非定常シミュレーションの結果である (BAE and KAYANE 1987)。グリッド間隔鉛は直方向の $\mathrm{k}$ が $10 \mathrm{~m}$, 水平方向の $\mathrm{i}$ と $\mathrm{j}$ がともに $100 \mathrm{~m}$ である。第 8 図では，地下の標高 $-170 \mathrm{~m}$ の水平面を不透水性の 基盤と仮定して計算し，等水理水頭線はー $170 \mathrm{~m}$ を基準面にとって示してある。地表起伏は小さすぎるの で図示してないが，等水理水頭線の分布から， $\mathrm{j}=7$ と29付近に開析谷が紙面と直交する方向に走っている ことがわかる。この断面上では, 点 $31,17,5$ で $231 \mathrm{~m}^{3} / \mathrm{day}$, 点 $31,7,16$ で $23.3 \mathrm{~m}^{3} / \mathrm{day}$ の揚水が行われて いる。初期の水理水頭分布が，揚水開始 5 日後，10日後と時間とともに変化する様子が理解できる。しか し計算結果によると，10日後以降は水理水頭分布パターンに顕著な変化は認められなかった。

第 8 図から, もしも点 $31,7,16$ の揚水量が点 $31,17,5$ 程度に大きくなれば, 開析谷の河川水が地下水中 へ引き込まれるであろうことは十分に予想できる。事実，筆者らはこの台地の湖岸に近い支谷の水田直下 で水理水頭の鉛直分布を測定し，その下向き勾配を確認している（未公表資料）。その原因の一つは，湖岸 低地で栽培している蓮根を掘るために使われる水ジェット用の地下水揚水と考えられる。

東京都の武蔵野台地を刻む河川は，その谷頭部および谷壁に多くの涌水をもち，かつては地下水で涵養 されていた清流であった。しかし現在では涌水の多くは涸渴し，谷頭にある善福寺池や井之頭池は揚水し た地下水の供給でかろうじて人工的に水位を保っている状態である。湧水や清流を復活させるには，総合 

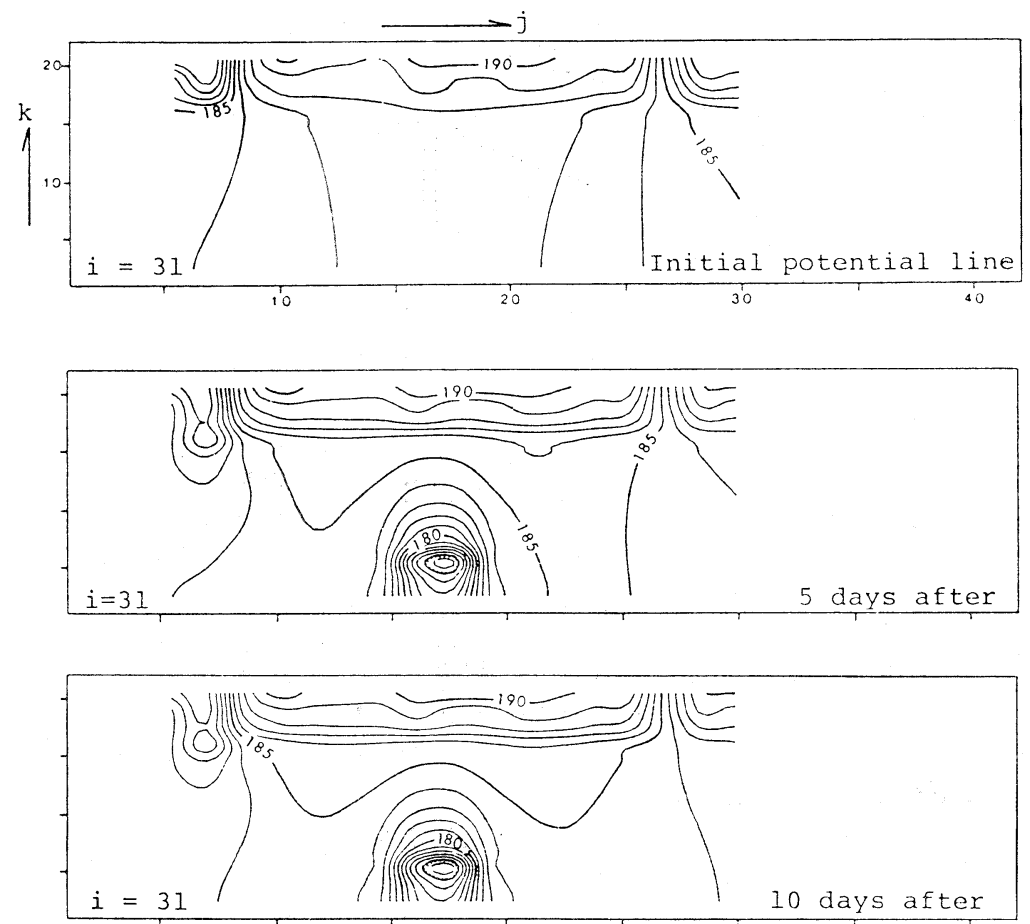

第 8 図出島台地の地下水三次元非定常シミュレーションの 1 例

(BAE and KAYANE 1987)

的な地下水管理が必要である。

火砕流が堆積して出来た台地は，前述の洪積台地と異なり，台地地下の地質構造が複雑で，地下水がい わゆる水みちを集中的に流れる点が特徵である。火砕流は高温な熱雲状態で流動し，堆積するため，既往 の地形が起伏に富むものであっても，それを埋めつくし，その上に平坦な台地面をつくる。火砕流自体は 透水性がいいので，台地面上に水流は発生しない。

このような水文地質条件のところでは，地下水は基盤地形や亀裂系の支配を強く受けて流動し，しばし ば地表水の流域界を横切る地下水の流れが生ずる。その1例は阿蘇火山西麓部の台地でみることができ, 下津ら（1979） は合志川や白川流域から加勢川流域へ大量の地下水流入があることを 流域間水収支によ って示している。そのため加勢川の渴水比流量は $4.0 \mathrm{~m}^{3} / \mathrm{s} \cdot 100 \mathrm{~km}^{2}$ と異常に大きくなっている（島野 1984）。なお，阿蘇カルデラ内に源を発し，この䐠流台地上を流れて有明海に注ぐ白川は，台地区間では 地下水を涵養する失水河川である（榧根ら 1987）。湿潤地域で河川が地下水の排水機能をもたない一例で ある。

\section{VIII. 扇状地の地下水}

沖積扇状地河川が山地から平地へ移行するところに発達する。扇状地の堆積物は砂䂢質で透水性にす ぐれ，現世の地形面でもあるため開析谷は発達していない。

扇状地における地下水のありかたの模式図が第 9 図である。扇状地面から涵養された地下水は扇端の湧 水帯で自噴する。黒部川扇状地のように直接海に面しているところでは，海底からの地下水流出もある。 扇状地の扇央部では地下水面が深く，地表面下 $10 \mathrm{~m}$ 以媣に位置することもある。したがって台地上の河川 
勇

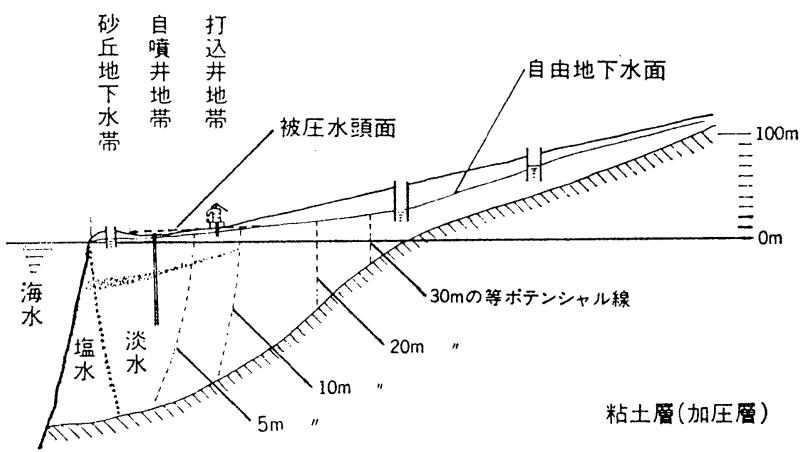

第 9 図黒部川扇状地における地下水の㐫りかたを示す模式 図（棑根・山本 1971）
同様扇状地上を流れる河川は，地下 水を涵養し，流下につれて流量を減 ビる。

ここで注意すべき点は，扇状地河 川の地下水涵養能力についてであ る。河川は線であるが，扇状地は面 である。扇状地の地下水の大部分は 地表面からの浸透によるもので，河 川からの涵養量は一般に考えられて いるほど多くはない（㨤根・山本

1971)。

\section{IX. 低地の地下水}

沖積平野の河川は基本的には地下水の排水系として 機能している。その例外が前述した扇状地の河川で ある。ただし，地形条件によっては，第10図のように河川が地下水を涵養している場合もある（石崎 1977)。利根川河道水収支によると，年平均流量で利根川の流量は，八斗島と古戸間で $31 \mathrm{~m}^{3} / \mathrm{s}$ 増加するが， 古戸から栗橋までの $34 \mathrm{Km}$ の区間では $28 \mathrm{~m}^{3} / \mathrm{s}$ 減少する。この減少分は第 10 図の地下水面形から明らかなよ うに，右岸側一地下水となって流出する。

信濃川は長岡市街地では，通常の状態では地下水を排水している（第11図左）。しかし冬季に大量の消雪 用地下水（豪雪時には 50 万 $\mathrm{m}^{3} / \mathrm{day}$ 以上）が揚水され，地下水面が著しく低下すると（第11図右）, 逆に河 川水が地下水を涵養するようになる。このような状態を誘発涵養とよぶが，誘発涵養は河川水々地下水が 連続していることを示す具体例である（榧根・谷口 1985）。

最後に，扇状地を除く勾配のゆるやかな沖積平野の地下水の流動経路について付言しておきたい。その ような場所では地下水面の勾配は $1 / 1000$ オーダーであるから，ダルシー式で計算すると，わずかな距離 を流動するにも著しく長い時間を必要とすることになる。しかし多くの場合，平野全体について描かれた

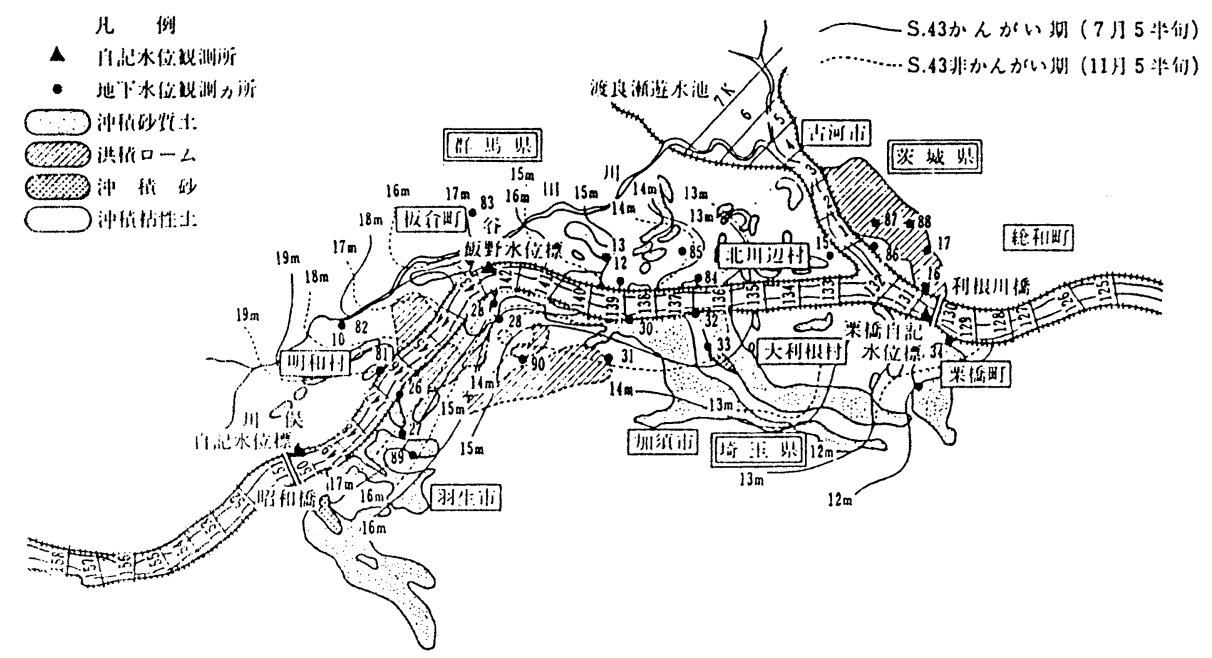

第10図 川俣一栗橋周辺における河川と地下水との関係（石崎 1977） 

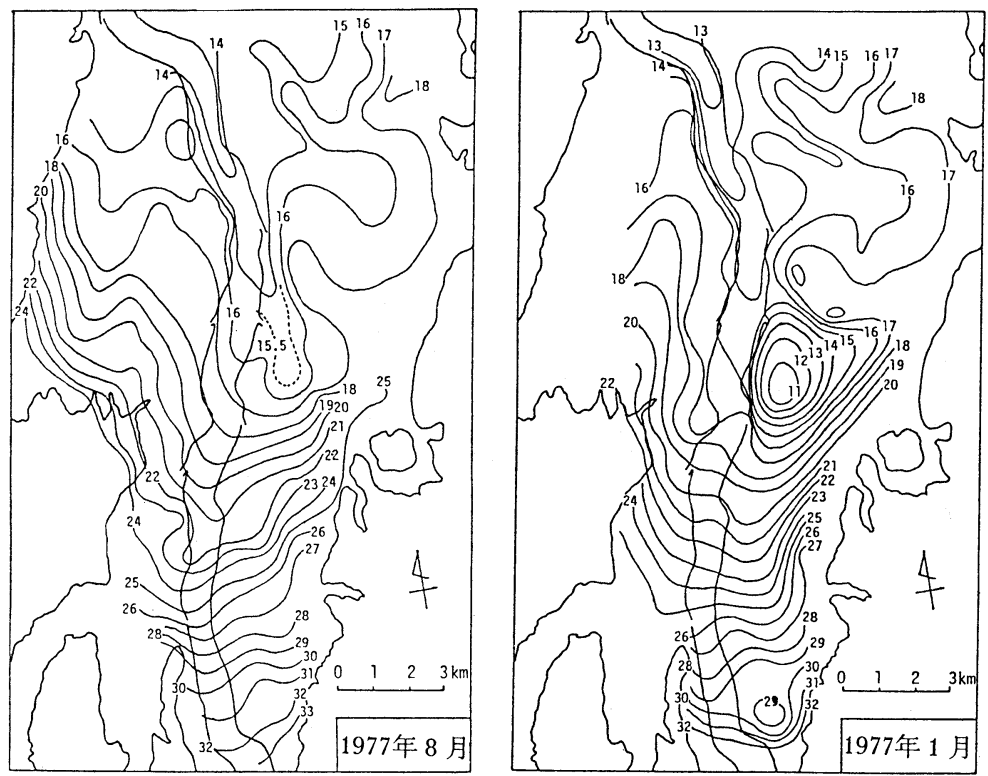

第11図 長岡に抢ける信濃川と周辺地下水との関係 地下水面標高は $\mathrm{m}$ （榧根・谷口 1985）

地下水面等高線図は，基礎となった地下水位の観測密度が十分ではないため，地表の微起伏に対応する地 下水面の微起伏を表現できるだけの精度は持っていない。現実には, 地下水はマク口にみた地下水面勾配 の方向にではなく，水路や小河川などに向から局地的な流動系を形成し，排水される場合が多い。地下水 流動系の研究によると，局地流動系とよばれるこれらの系は，地表から涵養された地下水の 80 ～90\%を排 水することが明らかになっている（ТóTH 1963）。

\section{引用文献}

BAE, S. K. and KAYANe, I. (1987) : A study of the three-dimensional groundwater flow system in an upland area of Japan. Hydrol. Process., 1, 339-358.

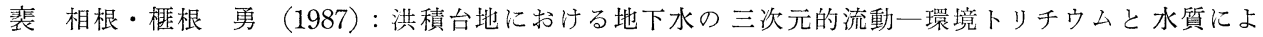
る地下水の循環と滞留時間一. 地下水学会誌, 29, 89-98.

DE VRIES, J. J. (1976); The groundwater outcrop-erosion model; Evolution of the stream network in The Netherlands. Jour. Hydrol., 29, 43-50.

石崎勝義（1977）：河川水と地下水. 建設月報，10月号，57-61.

榧根 勇・谷口真人 (1985) : 長岡平野の地下水 (III). 水利科学, $29(3), 1-17$.

——山本荘毅 (1971) : 扇状地の水循環。古今書院, 151p.

——島野安雄・田中伸廣（1987）：阿蘇西麓台地に拈ける地下水流動系。八イドロロジー, 17, 111120.

MARUI, A. (1986) : Subsurface water storage and runoff processes in a layered hillslope. D. Sc. Thesis, University of Tsukuba, 81p.

三宅紀治（1978a）：丘陵地小流域の流出特性，市川正巳・栕根 勇編「日本の水収支」，古今書院，7788.

(1978b)：大阪層群丘陵地の地下水と基底流出. 地下水学会誌，20，175-185.

百田博宣・嶋田 純・楠本 太 (1981)：原位置実測データを用いた岩盤内地下水流の解析的検討。 第25回水理講演会論文集, 391-397. 
中野尊正 (1963) : 日本のゼロメートル地帯. 東京大学出版会, $224 \mathrm{p}$.

太田猛彦・塚本良則・城戸 毅 (1985)：丘陵性自然斜面における雨水移動の実証的研究（II）, 斜面 内地中流の実態。日本林学会誌，67，383-390.

島野安雄 (1984) : 九州地方の河川諸流域の流出特性. 熊本大学文学部論叢, 12号, 73-104.

下津昌司 (1986)：阿蘇火山体における循環地下水の特性について。地下水学会誌，28，1-13.

——石崎勝義・北川 明 (1979）：広域水収支における地下水流動量の算定一阿蘇火山西麓部を例 として. 地下水学会誌，21，100-110.

新藤静夫 ・石川力 (1985): 霞ヶ浦北岸台地, 出島地域における地下水流動系の解析（第二報），地 下水学会誌, 27, 157-170.

TANAKA, T., SAKai, H., Marui, A. and Yasuhara, M. (1986): Can we explain stormflow hydrographs by the variable source area-overland flow concept? Ann. Rep. Inst. Geosci. Univ. Tsukuba, 12, 26-30.

Tóth, J. (1962): A theory of groundwater motion in small drainage basins in Central Alberta, Canada. Jour. Geophys. Res., 67, 4375-4387.

(1963) : A theoretical analysis of groundwater flow in small drainage basins. Jour. Geophys. Res., 68, 4795-4812.

山本荘毅 (1970) : 富士山の水文学的研究一火山体の水文学序説. 地理評，43，267-284.

YASUHARA, M. (1984): Watershed response to a storm rainfall. Sci. Rep. Inst. Geosci. Univ. Tsukuba, Sect. A, 5, 1-27.

(1988年10月 21 日受付，1989年 2 月 27 日受理) 